\title{
RESEARCH ON INVESTMENT APPEAL AND COMPETITIVE CAPACITY OF INDUSTRIAL ENTERPRISES OF UKRAINE
}

\author{
Olena Khadzhynova ${ }^{1}$, Victoriya Gonchar ${ }^{2}$, Oleksandr Kalinin ${ }^{3}$ \\ State Higher Educational Institution "Priazovskyi State Technical University", Ukraine
}

\begin{abstract}
The purpose of the research is an elaboration of theoretical, methodological, and methodical approaches to forming and developing competitive capacity and investment appeal of steel industry enterprises. The achievement of the given purpose has led to the necessity of formulating such scientific research concept, which bottom line is in the relevance of using modern management methods implemented in foreign manufacturing practices. These are innovative economic, technical, organizational, and corporate methods of managing enterprises with the help of developed systems of managing strategic changes in enterprise activities, the steel industry in particular, which will contribute to achieving the high level of effectiveness and competitiveness of domestic business units. The research methodology is based on the combination of theories of managing economic systems in the globalized market economy. The empirical base for the research consists of the works by domestic and foreign scientists on problems of formation and development of strategic change management systems at industrial enterprises, statistical records, companies' public records in the Internet, data of international information agencies, Ukrainian legislation on regulating economic activity of enterprises. In carrying out the research, such methods were used as: general academic analysis and synthesis, systemic generalization, statistic and correlation analysis (when justifying the directions of development before carrying out the economic analysis of activities of metallurgical enterprises). There is a conclusion that the industry is concentrated and, consequently, long-term trends are quite predictable, but they require additional clarifications, taking into consideration the uncertainty in the modern state of world economy. It is determined that metallurgy development depends on GBP. The analysis shows that the countries with the high GDP level have quite developed metallurgy. One of the main problems of modern industries (metallurgy included) is the problem of corporate management and its reactions to challenges of the external environment, which is becoming less and less predictable for analysts. We have presented the recommendations on improvement of strategic management to increase the investment appeal.
\end{abstract}

Key words: investment appeal, competitiveness, strategic management, industrial enterprises.

JEL Classification: G30, L1, L61

\section{Introduction}

Industrial enterprises require considerable financial resources to remain competitive. However, investors have to see the financial perspectives of their investments, thus there is an important question about the necessity of creating such mechanisms for managing enterprises, which will demonstrate investors the whole potential and importance of investing their funds in industrial enterprises. The investment appeal of an enterprise is a generalizing index of an investment object from the point of view of investment profitability, developmental prospects, and the level of investment risk.
The assessment of investment appeal of industrial and other enterprises is a strategic approach, targeted at the prevention or reduction of financial risk. There are many indicators used for the assessment of investment appeal. They are attributed to many requirements, prominent among which are the following: the amount of investments, their purpose, the nature of business operations of the enterprise, its commercial reputation, and credit history. We have selected metallurgical enterprises for the research subject as they are a demonstrative example of hard (in terms of analytics) and heavy investment industry, where the

\footnotetext{
Corresponding author:

${ }^{1}$ Department of Finance and Banking, State Higher Educational Institution "Priazovskyi State Technical University".

E-mail: azsudcom@gmail.com

${ }^{2}$ Department of Marketing and Business Administration, State Higher Educational Institution "Priazovskyi State Technical University".

E-mail: gonchar.mariupol@gmail.com

${ }^{3}$ Department of Marketing and Business Administration, State Higher Educational Institution "Priazovskyi State Technical University".

E-mail: kalininandkalinin@gmail.com
} 
demonstration of effective performance indicators is quite relevant for attracting additional investments.

Analysing the industry on the whole, it can be said that steel industry is still highly concentrated even on a global scale. All significant industrial assets and distribution channels are controlled by various international corporations or powerful national market leaders. Ukraine is not an exception here. Conclusions have also been drawn and recommendations have been given to national metal producers on the enhancement of investment appeal and competitive capacity in the medium-to-long term.

\section{The effectiveness of strategies of industrial enterprises}

One of the main aspects of the effective attraction of investors is the development of a strategy. On studying the current practice of the operation of the corporations, which have their assets in Ukrainian metallurgy, and the results of the expert survey, you can define the main/ basic strategies most common for steel industrial enterprises:

- strategies, targeted at minimization of labour costs. The final purpose of such enterprises is increasing the competitive capacity of their produce on the global market on the whole. In this case, it will comply with the further export orientation of the produce, which manufacturing is moved to the local market, presenting an opportunity for improving the country's balance of payments. On the other hand, the declaration of such a strategy might hide the policy of the main corporation targeted at overcoming the protectionist barriers.

- market-oriented strategies, which are the most common, first of all, for the world leaders whose goal is to get access to serving the global markets. The Ukrainian market is attractive for such corporations because of its size and geopolitical situation, which give an opportunity of getting access to the whole regional market of post-Soviet countries.

- the strategy oriented to the search for scarce or cheaper raw materials. Such a strategy is characteristic of the corporations operating in mining industries or processing raw materials. They are interested in creating vertically integrated structures by including in them enterprises existing on the territory of Ukraine. As for the possible consequences of such corporate strategy for Ukraine, this problem should be examined in terms of possibilities for recovery or non-recovery of mentioned resources, and necessity of maintaining national sovereignty over strategically significant ones for the further development of the state.

Price fluctuations on the global market might cause the considerable deterioration of trade conditions for the country, the significant part of which export is the produce, which prices have sharply declined. The assessment of the concentration level is made on the basis of calculating economic indicators of activities of steel enterprises. The main quantitative characteristic of the market structure is concentration. It is the degree of prevalence of one or several independent business units (manufacturers) in the system of manufacturing fungible goods supplied to the same geographical market. The concentration indexes reflect, in particular, the balance between the number of enterprises and distribution of market shares. The modern economic theory and statistics offer approximately 20 integrative concentration indexes (Besanko, Dranove, Shanley \& Schaefer, 2009). Concentration indexes are based on the comparison of the enterprise size to the size of the market it operates on. The bigger the size of the enterprise in comparison to the scale of the whole market, the higher is the concentration of manufacturers (sellers) in this market. The most common among them are: the Herfindahl-Hirschman index (HHI) and the Tideman-Hall index.

The maximum value of the Tideman-Hall index is 1 (when there is a monopoly). The minimum value is $1 / \mathrm{n}$. This index is similar to the Herfindahl-Hirschman index in its effect but the Tideman-Hall allows the possibility of ranging enterprises according to the degree of significance, thereby contributing to the deeper analysis of the industry.

In order to identify the competitive capacity of domestic steel enterprises, let us calculate the mentioned above indexes for the flat steel market. The analysis of prospects of integration processes and manufacturing cooperation development shows that the vertical intraindustry trade becomes more important. In this case, export and import are products of different stages of the technological process. It is the exchange of parts and components or output within one and the same industry or exchange of parts, components or raw materials into the finished product of the same industry. Such a trade takes place when there are discrepancies in production factors of trade partners. The driving forces of growing and developing such a kind of intraindustry trade are mainly suppliedside factors. The basis of the vertical intra-industry trade is detailed and sometimes technological specialization, which gives the chance to fully use the saving from the production scale. The necessary condition for the development of intra-industry trade is the size of the market, ensured by economic integration. Thus, intra-industry trade share is often used as one of the characteristics of integration intensity on the territory of the country. There are several indexes measuring intra-industry trade (the Verdoorn index, the Balas index), but the most common is the index proposed in 1975 by H. Grubel and P. Lloyd (Grubel, Herbert; Lloyd, Peter, 1975). Intra-industry trade: the theory and measurement of international trade in differentiated products.

The index allows assessing the share of intra-industry trade in the general volume of trade of this country 
Table 1

The concentration of flat steel market for 2011-2016

\begin{tabular}{|l|c|c|c|c|c|c|c|c|}
\hline \multirow{3}{*}{ Country } & \multicolumn{2}{|c|}{$\begin{array}{c}\text { Production volume (thousand } \\
\text { tons }\end{array}$} & \multirow{2}{*}{$\begin{array}{c}\text { Pace of change, } \\
\text { \% }\end{array}$} & \multicolumn{2}{|c|}{$\mathrm{R}$} & \multirow{2}{*}{ qi } & \multirow{2}{*}{ qi2 } & \multirow{2}{*}{ R*qi $^{*}$} \\
\cline { 2 - 3 } & 2011 & 2016 & & 2011 & 2016 & & & \\
\hline China & 683265 & 808366 & 18,31 & 1 & 1 & 45,854 & 2102,669 & 0,458 \\
\hline Japan & 107595 & 104775 & $-2,62$ & 2 & 2 & 7,22 & 52,14 & 0,144 \\
\hline The USA & 86247 & 78465 & $-9,02$ & 3 & 4 & 5,788 & 33,503 & 0,173 \\
\hline India & 72200 & 95477 & 32,24 & 4 & 3 & 4,845 & 23,478 & 0,193 \\
\hline Russia & 68743 & 70808 & 3,00 & 5 & 5 & 4,613 & 21,284 & 0,23 \\
\hline South Korea & 68471 & 68576 & 0,15 & 6 & 6 & 4,595 & 21,115 & 0,275 \\
\hline Germany & 44288 & 42080 & $-4,99$ & 7 & 7 & 2,972 & 8,834 & 0,208 \\
\hline Ukraine & 35332 & 24218 & $-31,46$ & 8 & 10 & 2,371 & 5,622 & 0,189 \\
\hline Brazil & 35162 & 31275 & $-11,05$ & 9 & 9 & 2,359 & 5,568 & 0,212 \\
\hline Turkey & 34103 & 33163 & $-2,76$ & 10 & 8 & 2,288 & 5,238 & 0,228 \\
\hline Total & 1235406 & 1357203 & 9,86 & & & 100 & 2293,8525 & 588,12 \\
\hline In the world & 1538003 & 1628049 & 5,85 & & & & & \\
\hline
\end{tabular}

The source: calculated by the authors on the basis of the data on www.worldsteel.org.

with another country, a group of countries or with all the other countries of the world. If the industry product $\mathrm{k}$ is only exported or only imported, then the value of Gruber-Lloyd index is 0 , which shows the complete absence of intra-industry trade. When countries export and import the equal amount of the same goods, the index value is 1: it means that all the trade has the intraindustrial nature. The technical factor, affecting the index value is the level of data detail: the higher it is, the higher the index value obtained.

The Herfindahl-Hirschman and the Tideman-Hall indexes show that the global market is still highly concentrated because of mergers and acquisitions among the leading manufacturers of flat steel. The main force in this market will be the vertical integration, which will give considerable competitive advantages over the non-integrated structure. The results of calculations for concentration indexes are given in Table 1.

We can draw the conclusions that by 2016 most of the countries-steel manufacturers hardly changed their positions. The general tendency is the growth of production capacities of Asian countries where the fastest economic growth can be observed and there is a powerful domestic market (China and India in the first place). The main competitive advantage is the opportunity to supply high-quality products like countries of Western Europe or through competitive price, achieved of scale and productivity of cheap labour (China, India) or cheap resources (RF). The analysis has also shown that because of this industry's cyclical nature, the appearance of fundamentally new players on the market is unlikely. The conclusions have been drawn according to the concentration of manufacturers on the world market and method of this index calculation (Table 2).

One of the conclusions is the clear tendency that on the wave of economic recession, mergers of world
Table 2

Estimates of concentration indexes of the flat steel market

\begin{tabular}{|c|c|c|}
\hline Index Name & $\begin{array}{c}\text { Index dynamics } \\
\text { 2011-2016 }\end{array}$ & Concentration level \\
\hline $\begin{array}{c}\text { Concentration } \\
\text { Index (CR) }\end{array}$ & $56,87-76,08$ & $\begin{array}{c}\text { High on the world flat } \\
\text { steel market }\end{array}$ \\
\hline $\begin{array}{c}\text { Herfindahl- } \\
\text { Hirschman index } \\
\text { (HHI) }\end{array}$ & $941-3261$ & $\begin{array}{c}\text { The world market is } \\
\text { highly concentrated }\end{array}$ \\
\hline $\begin{array}{c}\text { Hall-Tideman index } \\
(\mathrm{HT})\end{array}$ & $0,14-0,256$ & $\begin{array}{c}\text { Medium level of } \\
\text { industry concentration }\end{array}$ \\
\hline Grubel-Lloyd index & $0,109-0,224$ & $\begin{array}{c}\text { Low level of intra- } \\
\text { industry concentration }\end{array}$ \\
\hline
\end{tabular}

leaders in flat steel manufacturing can be expected. So, it might be a big threat for the positions of Ukrainian enterprises and might cause integration with domestic or foreign enterprises - competitors (or suppliers of raw materials).

Against this background, it seems that domestic steel enterprises should be protected by the introduction of high customs barriers for foreign goods. As a result, domestic manufacturers do not acquire skills necessary for international competition. The customers suffer, too. Enterprise managers should recognize these manifestations, monitor them, and identify development tendencies and possible forms of their influence on the enterprise.

Based on the share of the produce of steel industry in the volume of Ukrainian export, it is logical to assume its impact on the value of export concentration. The empirical research has proved the previously formulated hypothesis, under which there is a very close link between concentration indexes in the metallurgical industry of Ukraine.

Thus, the volume of net export of Ukraine is sensitive to opportunistic fluctuations on the world market 
of steel and ferrous metals. So we can speak about the necessity of conducting integration processes in Ukraine, targeted at increasing the product quality and volume of production and export. The main thing is to ensure the organic fitting of the development of international economic ties of Ukraine on the whole and those with the EU countries in particular, in the general strategy of the transformation of the Ukrainian economy. The main task is to develop our own economic model and select such a set of indicative ratios, which will promote the steady economic growth. Meanwhile, the achievement of criteria-based convergence will be only the intermediate stage on the common road.

The analysis of strategic requirements in metallurgy, the study of stages of development allowed working out the conceptual model of the system of the impact of determining parameters of the external environment on the strategic changes of enterprises of steel industry (Fig. 1).
The proposed model provides for conducting an assessment of the impact of external environmental factors in three stages.

On the first stage, the enterprise management should decide, which determining parameters of external environment will directly influence the competitive capacity of an enterprise. It would be useful to conduct research on five forces of competition proposed by M. Porter: competitors, substitutes, customers, industrial customers, and suppliers (Porter, 2008).

On the second stage, external environment changes and their threats are studied, this is the process, which concerns all levels of an enterprise and lasts for several months. The process is so complicated that enterprises cannot cope with the changes, introduced by the government, foreign competitors, and technical progress with its sudden advances. To cope with such changeable tasks, it is suggested that enterprises should

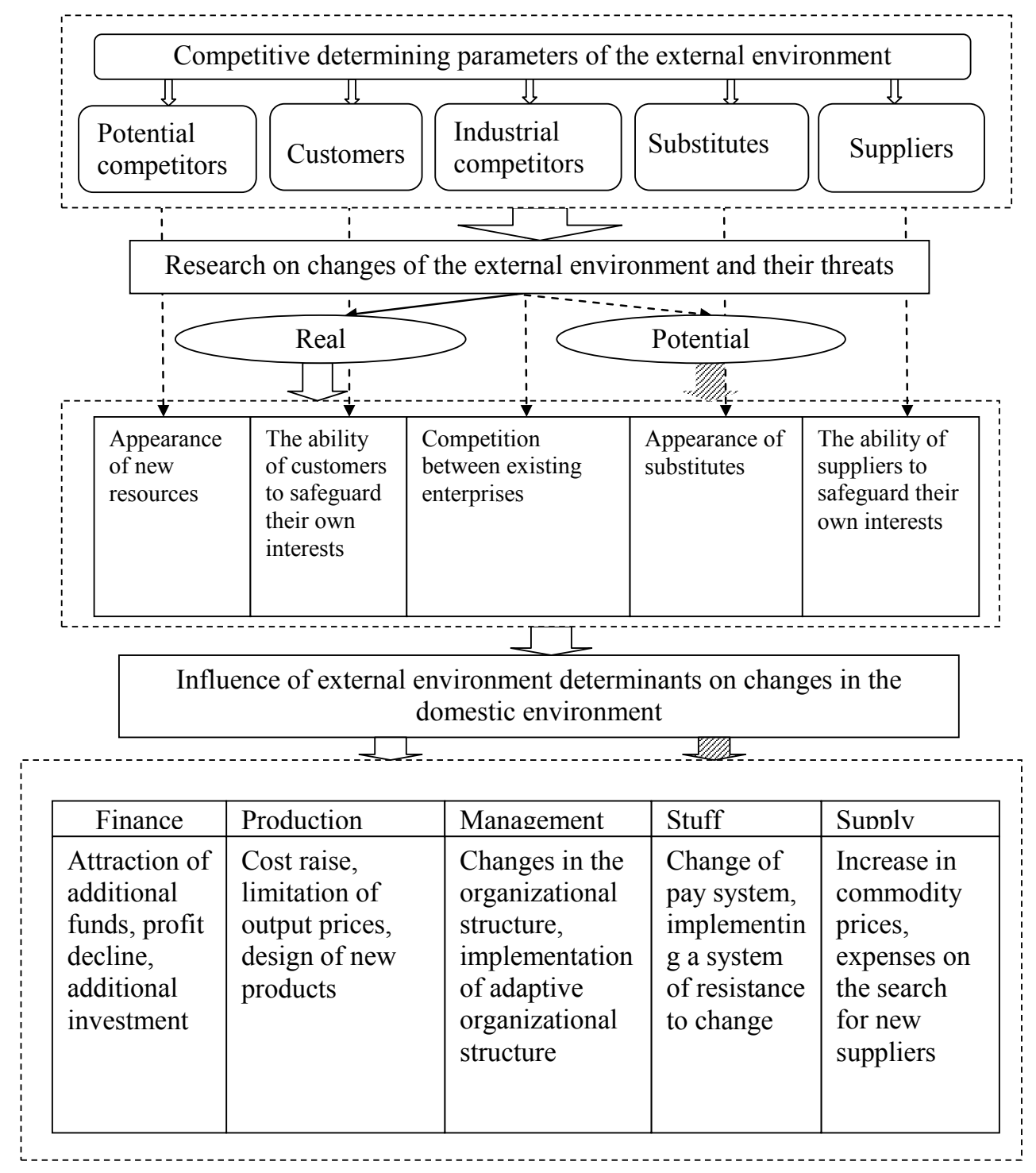

Fig. 1. The conceptual model of the system of the impact of determining parameters of the external environment on strategic changes of steel industry enterprises 
adopt the principle of timely decisions and form the management system by means of ranking strategic tasks.

Taking into consideration the fact that this stage is essential for the further creation of a system of strategic change management and elaboration of a development strategy of the enterprise, which should take into consideration the development strategy of the corporation, of which it forms a part, there is a need in designing the model of interaction between the enterprise and the corporation on this stage (Fig. 2).

This system of the impact of determining parameters of strategic management can easily be mastered and used. It includes the following:

1. Constant monitoring all the tendencies in external environment: marketing, technical, economic, social, and political.

2. Reporting the results of analysis of these tendencies and assessment of the degree of decision urgency to the top management of an enterprise at regular meetings and as new threats emerge and new opportunities are discovered.

3. The top management and the planning department of an enterprise divide all the tasks into three categories: a) urgent and important tasks demanding immediate consideration; b) targets demanding constant monitoring; c) postponed tasks, not worth further consideration. It is proposed to rank the tasks using Table 3, which is a simple form of recording the results of this analysis.

As can be seen from this form, the next is the time score of appropriate response to each possible development. Such a score is obtained by comparing the probable time of event impact with the time the enterprise needs for a timely response. Such scores can be used for the classification of events according to the time of response: high (changes require immediate response to events); medium (the proper response to changes can be postponed until the next planning cycle); low (reportedly, the appropriate response can be



Fig. 2. The model of interaction between the enterprise and the corporation on the stage of strategic management of intensification of industrial activities 
Table 3

Consequences of changes in the external environment of an enterprise

\begin{tabular}{|c|c|c|c|c|c|c|}
\hline Factor & Changes & Time of change consequences & $\begin{array}{l}\text { Speed of appropriate } \\
\text { response }\end{array}$ & Risks of losses & Capacities & $\begin{array}{c}\text { Category } \\
\text { of strategic } \\
\text { objectives }\end{array}$ \\
\hline \multirow{3}{*}{$\mathrm{N}$} & N1 & Immediately & High & $\begin{array}{l}\mathrm{Z}_{11} \\
\cdots \\
\mathrm{Z}_{1 \mathrm{n}}\end{array}$ & $\begin{array}{c}M_{11} \\
\ldots \\
M_{1 n}\end{array}$ & $\begin{array}{c}\text { Create a target } \\
\text { group }\end{array}$ \\
\hline & $\mathrm{N} 2$ & The next planning time & Medium & $\begin{array}{l}\mathrm{Z}_{21} \\
\cdots \\
\mathrm{Z}_{2 \mathrm{n}}\end{array}$ & $\begin{array}{c}M_{21} \\
\ldots \\
M_{2 n}\end{array}$ & $\begin{array}{l}\text { Continue } \\
\text { monitoring }\end{array}$ \\
\hline & N3 & Not defined (long) & Low & $\begin{array}{c}\mathrm{Z}_{31} \\
\cdots \\
\mathrm{Z}_{3 \mathrm{n}}\end{array}$ & $\begin{array}{c}\text { M31 } \\
\ldots \\
M_{3 n}\end{array}$ & $\begin{array}{l}\text { Response } \\
\text { postponed }\end{array}$ \\
\hline
\end{tabular}

postponed indefinitely - till obtaining a more accurate assessment of possible consequences). Strategic objectives, which consequences are rated, for instance, as \pm 3 points on a scale of 1 to 10 , are categorized as insignificant and excluded from further consideration. These objectives should be divided according to the degree of significance in compliance with expected consequences. This will result in obtaining the list of key strategic objectives of an enterprise, used for managing the system of strategic changes. This list is corrected by excluding the solved objectives and insignificant consequences, and including new ones. The list of key objectives helps solve problems, especially if these problems are faced for the first time. The challenge is that the number of key objectives sometimes exceeds the enterprise capabilities to address them. Methods of identifying key strategic objectives help shorten the list and define priorities within available resources.

4. Urgent tasks are given for studying and decisionmaking either to the existing divisions of the enterprise or to special operational units, which can be quickly involved if necessary.

5. Decision-making is controlled by the top management with regard to possible strategic and tactical consequences.

6. The top management regularly reviews changes caused by the external environment.

Stage 3. As shown in Fig. 1, the next stage in analysing strategic objectives is the assessment of the impact of potential future consequences of external environment changes on the future results of the enterprise activities. The ideal approach is to assess the impact of the environment changes on the achievement of objectives of the enterprise. However, there is often no necessary information or the method of its assessment is not defined. Instead, you can identify consequences of each tendency on a scale from 0 to -10 , giving a certain score based on expert judgement. Such a judgement is made by a group of experts, which includes enterprise managers and external specialists possessing appropriate knowledge and skills. Besides the consequences themselves, it is necessary to assess their probability and time of their appearance. The consequences can be positive (strengths and weaknesses of an enterprise) or negative (risks of losses) or both. The last case demonstrates a degree of uncertainty in assessment or the chance that any consequences might turn out to be both useful (contribute to the achievement of some goals), and harmful (cause poor progressing in the achievement of other goals) for the enterprise.

\section{The influence of forecasting on the investment appeal}

The effective forecasting has always been connected with creating development strategies and investment appeal of enterprises. But forecasting techniques the most effective 15-20 years ago are showing the sharp decline in their effectiveness over the dynamics of economic factors. Forecasting of the dynamics in different economic sectors requires modification of methods taking into account individual tendencies characteristic for this or that sector. Thus, despite the long-term study, the problem remains relevant and requires constant updating in accordance with current market tendencies.

There are three main approaches to methods of forecasting market dynamics: traditional (genetic) - the retrospective analysis of the actual number of requests for services and heuristic heuristics way main tendencies, determining their future amount; classical - forecast taking into consideration the limited number of dominant factors (usually - income and prices); modified adaptation of the classical approach to modern complex process of generating a demand for service products.

In forecasting dynamics of sales of steel industry products for the development of the system of strategic change management, there is a constant need in making difficult decisions connected with considering many quality criteria and restrictions on resources. Creation of adaptive systems will allow carrying out the active adaptation to volatile conditions and requirements of the external environment. Forecasting for the countries - exporters of metal products is built on the 
Table 4

The output, grouped on a geographical basis*

\begin{tabular}{|l|c|c|c|c|c|c|c|c|c|c|c|}
\hline \multicolumn{1}{|c|}{ Region } & 2007 & 2008 & 2009 & 2010 & 2011 & 2012 & 2013 & 2014 & 2015 & 2016 & $\begin{array}{c}2016 / \\
2007, \%\end{array}$ \\
\hline European Union & 210260 & 198705 & 139436 & 172911 & 177791 & 168589 & 166356 & 169301 & 166115 & $\begin{array}{c}1 \\
62024\end{array}$ & $-22,94$ \\
\hline Other Europe & 30533 & 31621 & 29034 & 33650 & 39079 & 39917 & 38627 & 38374 & 35778 & 37651 & 23,31 \\
\hline C.I.S. & 124169 & 114345 & 97691 & 108200 & 112663 & 110739 & 108408 & 106079 & 101552 & 102410 & $-17,52$ \\
\hline North America & 132618 & 125138 & 83772 & 111562 & 118675 & 121586 & 118978 & 121093 & 110938 & 110624 & $-16,58$ \\
\hline South America & 48232 & 47490 & 37776 & 43888 & 48165 & 46379 & 45822 & 45043 & 43899 & 40220 & $-16,61$ \\
\hline Africa & 18675 & 16970 & 15400 & 16624 & 15696 & 15337 & 15963 & 14885 & 13701 & 13099 & $-29,86$ \\
\hline Middle East & 16452 & 16646 & 17766 & 20000 & 23230 & 24979 & 26967 & 29986 & 29429 & 31480 & 91,34 \\
\hline Asia & 758385 & 784090 & 811866 & 918449 & 995457 & 1026801 & 1123646 & 1139222 & 1112873 & 1124704 & 48,30 \\
\hline Oceania & 8783 & 8424 & 6014 & 8149 & 7248 & 5805 & 5588 & 5466 & 5717 & 5837 & $-33,54$ \\
\hline World & 1348108 & 1343429 & 1238755 & 1433433 & 1538003 & 1560131 & 1650354 & 1669450 & 1620001 & 1628049 & 20,77 \\
\hline
\end{tabular}

The source: calculated by the authors on the basis of the data on www.worldsteel.org.

fact that metallurgy in these countries is the leading industry and significantly influences the gross domestic product (GDP). Let us make the correlation analysis to check this hypothesis. Steel production figures $\{\mathrm{x}\}$ serve as factorial indicators of correlation analysis and GDP data serve as output indicators. The research used the output figures of countries grouped on a geographical basis (Table 4), in accordance with the data given by World Steel Association.

The following regions were identified:

Grouping of countries in the region allows identifying the market tendencies more accurately, in doing so summarizing the number of various tendencies in national markets.

The objective of this analysis is the identification of regions where there expected an increase in demand for steel, duration of this dynamics, factors influencing it, and the identification of regions, which are increasing local production and will squeeze out foreign manufacturers, and determination of the time when regions-importers will become exporters. The data for the analysis are output and consumption figures, GDP data on purchasing power at current prices in US dollars, per capita steel consumption. GDP data are used for the identification of general economic tendencies in the regions of the world. The dependence of production on GDP growth is attributed to the use of steel in all sectors of national economy.

Within the given array of indicators, the correlation rates have been calculated according to the formula:

$$
r_{X Y}=\frac{\sum\left(X_{i}-\bar{X}\right)\left(Y_{i}-\bar{Y}\right)}{\sqrt{\sum\left(X_{i}-\bar{X}_{i}\right)^{2} \sum\left(Y_{i}-\bar{Y}\right)^{2}}},
$$

where $X$ - a factorial indicator of steel production data, thousand tons,

$Y$ - output indicator of the country's GDP, billion US dollars

The assessment of the correlation between the indexes of rolled steel production $\{x\}$ and GDP by regions of the world $\{y\}$ (Table 5).
Table 5

Assessment of correlation between indexes of rolled steel production $\{\mathbf{x}\}$ and GDP by regions of the world $\{y\}$

\begin{tabular}{|l|c|c|}
\hline \multicolumn{1}{|c|}{ Part of the world } & Correlation rate & Regression equation \\
\hline The EU & 0,08 & $\mathrm{y}=-3,7064 \mathrm{x}+238796$ \\
\hline European countries & 0,98 & $\mathrm{y}=21,421 \mathrm{x}-4850,3$ \\
\hline CIS & 0,26 & $\mathrm{y}=3,9018 \mathrm{x}+101131$ \\
\hline North America & 0,08 & $\mathrm{y}=1,00158 \mathrm{x}+40233$ \\
\hline South America & 0,28 & $\mathrm{y}=1,2343 \mathrm{x}+40237$ \\
\hline Africa & 0,01 & $\mathrm{y}=-0,337 \mathrm{x}+17477$ \\
\hline Middle East & 0,84 & $\mathrm{y}=7,2417 \mathrm{x}+2927,5$ \\
\hline Asia & 0,98 & $\mathrm{y}=40,407 \mathrm{x}-74492$ \\
\hline Total & 0,94 & $\mathrm{y}=17,281 \mathrm{x}+136610$ \\
\hline
\end{tabular}

The analysis of the dependence of steel production on GDP has shown that the amount of crude steel production is correlated with GDP. The dependence figures are reflecting a steady tendency of GDP growth in the world, which is stimulating the increase in steel production. On average, the world GDP growth on $\$ 17,281,000$ provides the output growth of 1,000 ton. To figure out the reasons for the absence of correlation in the countries of the EU, CIS, South and North America and Africa, let us consider per capita consumption of manufactured steel products in these regions. This index is the most accurate in reflecting the level of steel use in a country's economy, showing the people's needs for the industrial production. In the most developed regions of the world (countries of North America and the EU) on average 264.57 and $338.5 \mathrm{~kg} /$ capita was consumed from 2002 to 2011, the biggest amount of steel per capita was consumed in the United Arab Emirates in 2008 $2210.9 \mathrm{~kg} /$ capita.

According to the conducted research, there was the increase in GDP and production output in those regions of the world where since 2002 the population's consumption of steel consumption was well behind the consumption in more developed regions: the EU and North American countries. However, rapid economic 
growth (2002-2011 GDP growth in countries of Europe $-73.3 \%$, Middle East $-89.8 \%$, countries of Asia $116 \%$ ) stimulated domestic demand in the region, which in turn led to the considerable production growth in the regions. It is observed in the countries of Asia, Europe, and the Middle East. The most developed countries: the EU, the USA, Canada, Japan, South Korea where per capita GDP was high during the period in review, experienced only fluctuations of steel consumption, depending on the economic situation in the region. Consumption figures in these regions are used as the upper boundary, on reaching which GDP growth stops significantly affecting output and consumption in the regions. The continuation of the tendency for output growth in the regions will lead to the urgent need for new export markets, and that will make them competitors of Ukrainian steel industry. As for the countries of South America and Africa, they are characterized by low level of production and consumption, without considerable growth tendencies. CIS market is characterized by the significant dominance of manufactured products over domestic demand for it. Such a situation forces to search for external markets, while domestic consumption is, in fact, underdeveloped ( $201 \mathrm{~kg} /$ capita) is far below that of neighbouring countries of Europe ( $252 \mathrm{~kg} /$ capita).

According to the obtained data from analysis of correlation of output, GDP, and per capita steel production, the forecast was made as for the output up to $2017.35 \%$ output growth is predicted in the world.

The forecast shows that by 2016 per capita consumption in Asian countries will exceed the average in the EU in 2002-2011 and then it is possible to expect the decline in production growth rates in the region. This boundary in European and Middle Eastern countries will be reached by 2018 provided that the current tendencies remain unaffected.

The conducted research has allowed creating the forecast of steel production dynamics in the world, of the market of Asian, Middle Eastern and European countries up to 2017 based on general economic tendencies and market demand for metallurgy output from final consumer. The improvement in the effectiveness of forecasting of steel enterprises provides an opportunity for early production reorganization in accordance with increasing demand. The improvement of techniques for predicting regional competition allows raising the level of management information support, which has a positive impact on the quality of devised competition risk mitigation measures. According to the obtained forecast, following current economic trends, it should be expected by 2016-2017, provided the domestic demand is satisfied by steel manufacturers of Asian, European, and Middle Eastern countries. The predicted volume of domestic production, which will ensure market saturation for the countries of Europe is estimated at 50047 thousand tons, for the Middle East - 25752.98 thousand tons, for Asia 1613941 thousand tons.
So far it is rather difficult to assess factors and criteria of effectiveness of a business unit's activities on different stages of industrial life cycle. It has been empirically identified that those enterprises, which managed to implement their research on the industry's early development stages, continued to earn the highest profit. It has a lot to do with economies of scale, which is achieved by those who were the earliest to introduce their innovations to the market. Thus, as the scientists have shown, the technological advantage, especially on the early stages of industrial development, can become the source of steady competitive benefits in the future.

If this variety of approaches is summarized and the development stages of the steel industry are taking into consideration, we can assume that on the whole four main stages of development are identified in the enterprise life cycle: formation, growth, stabilization, and decline, when the last one can turn into the stage of revival. The results of correlation and interaction between the enterprise life cycle and strategic changes of production are demonstrated on the data of Metinvest Holding LLC.

For the identification of life cycle stages of Metinvest Holding LLC, the technique is proposed based on the identification of 7 activity indexes, which values can help identify the stage in the life cycle of an industrial enterprise. These are, in particular, the balance structure and dynamics (the correlation between receivables and payables), indexes of financial resilience, solvency indicators, the profitability of sales, and assessment of marketing potential of the enterprise (market share of the enterprise), sales growth rate and the degree of market concentration. Restrictions for these indexes have been set (based on statistics on the activities of metallurgical enterprises) with the view to their practical application.

The calculations of the sales growth rates within the analysed period will not show the actual situation because 2008-2016 years are considered the time of crisis for the whole metallurgical industry and are characterized by a considerable decline in sales and output accordingly. That is why, to describe the growth rates, it is logical to use performance indexes of the enterprise in comparison with those of the industry. Assuming that Metinvest Holding LLC is one of the oldest metallurgical enterprises of the country with a well-organized marketing system, we will consider the sales growth rate above average.

6. The marketing potential of the enterprise (market share).

Ukraine represents about 3-4\% of world metal production. Of these, the share of Metinvest Holding LLC is estimated at $55-70 \%$. Taking into consideration the fact that there are 15 metallurgical enterprises in Ukraine, it can be argued that its share is relatively large.

7. The degree of market concentration

As Metinvest Holding LLC is an export-oriented enterprise, the assessment of the degree of market 
concentration should be based on the world metallurgy market. This market is represented by a large number of plants, which exceeds the index of 2000 enterprises, so it is considered highly concentrated.

The given above calculations allow the conclusion that Metinvest Holding LLC is on the lifecycle stage "Stabilization", that is, our assumptions have been proved. For this stage, we recommend the strategies targeted at long-term perspectives of the stable operation of the enterprise. Considering the stage of the life cycle and the need to increase its stability in the long-term perspective, it is recommended to apply the strategy of viability (the strategy oflong-term development), aimed at the insurance of stable development and operation rates of the enterprise. Within this strategy, one of the main objectives is the introduction of the procedure of recording the impact of external factors. The actions the enterprise management should implement on different stages of the life cycle are described in Table 6.

Table 6

The content of activities of industrial enterprises according to the stage of the lifecycle

\begin{tabular}{|c|c|c|}
\hline \multicolumn{2}{|c|}{ Stable situation } & \multirow{2}{*}{$\begin{array}{l}\text { Crisis situation } \\
\text { "Decline", "Revival" }\end{array}$} \\
\hline $\begin{array}{c}\text { "Formation", } \\
\text { "Intensive growth" }\end{array}$ & "Stabilization" & \\
\hline $\begin{array}{l}\text { Optimization of } \\
\text { business processes }\end{array}$ & $\begin{array}{l}\text { Maintaining the level } \\
\text { of production of } \\
\text { competitive goods } \\
\text { for the enterprise }\end{array}$ & $\begin{array}{c}\text { Restructurisation } \\
\text { with minimal risk } \\
\text { level after reaching } \\
\text { zero or close to zero } \\
\text { business value }\end{array}$ \\
\hline $\begin{array}{l}\text { Improvement of } \\
\text { the organizational } \\
\text { structure of an } \\
\text { enterprise }\end{array}$ & $\begin{array}{c}\text { Alignment of } \\
\text { own management } \\
\text { resources with the } \\
\text { potential of identified } \\
\text { capabilities and } \\
\text { shortcomings }\end{array}$ & $\begin{array}{l}\text { Addressing both } \\
\text { creditors' interests } \\
\text { and the minimum } \\
\text { demands of } \\
\text { enterprise owners }\end{array}$ \\
\hline $\begin{array}{c}\text { Improvement } \\
\text { of the system of } \\
\text { capital and finance } \\
\text { management }\end{array}$ & $\begin{array}{l}\text { Coordination of own } \\
\text { capabilities with the } \\
\text { interests of segments } \\
\text { of consumers }\end{array}$ & $\begin{array}{l}\text { Commitment to } \\
\text { reach the maximum } \\
\text { business value }\end{array}$ \\
\hline $\begin{array}{l}\text { Identifying the } \\
\text { growth points }\end{array}$ & $\begin{array}{l}\text { Orientation to } \\
\text { the target market } \\
\text { with the objective } \\
\text { to realize own } \\
\text { competition benefits }\end{array}$ & \\
\hline
\end{tabular}

In the current market context, it is the appropriate response of enterprise production to the growing factor of uncertainty of external environment that is one of the most relevant and acute problems of functioning and development of any business. Strategic changes of an enterprise, consistent with the changes of its external environment are of vital importance. The relevance of these changes is connected with objective modern tendencies that determine the nearest long-term perspectives of market development. Thus, strategic changes, as already stated, are the most valuable content of any strategy. All of these strategic changes are the main carriers of the new quality in the process of the enterprise development, and namely strategic changes are the key object of management in realizing both separate functional strategies and corporate strategy on the whole. Any change means transferring the change target from one state to another.

Based on the principles of forecast formation, three groups of methods can be identified: extrapolation, simulation, and expert judgement. Extrapolation techniques (the smallest squares, moving averages, exponential smoothing etc.) draw on the statistically sound change tendencies of these or those objects' quantitative characteristics. Extrapolation techniques are one of the most common methods of economic forecasting. Extrapolation is defined as a way of estimating, beyond the original observation range, the value of a variable on the basis of its relationship with another variable.

Simulation methods include techniques of structural, network, matrix, and other ones, which provide an opportunity to obtain forecasting financial data with the help of certain models.

Methods of expert judgement belong to informalized ones and are used in the case when it is impossible to take into consideration the impact of many factors due to considerable complexity of forecasting objects. When it is impossible to apply formalized forecasting methods, we have to resort to knowledge and experience of experts.

The essence of the forecasting technique with the help of sales percentage lies in increase (decrease) index of the income from product sales (services), balancing items and statement on financial performance (except those not depending on the sales' change) of the same per cent. The assumption about the direct correlation between the income change rates should be verified on the base of empirical data.

Forecasting using regression method (provided that there is a linear or non-linear correlation between forecast indexes) allows obtaining the future value of the quantitative index, which is random, depending on fluctuations in one or several indicators.

Forecasting with the help of normative approach is aimed at receiving the optimal balance and statement on financial performance based on the following: capital profitability, liquidity etc. The similar prediction is used to assess those changes in the assets and the sources of their establishment, which are essential in the future to achieve optimal profitability and stable financial situation.

The technique of creating projected financial statements based on standard ratios is widely used by the enterprises, the management of which is built on the concept of strategic controlling.

Sometimes it is useful to make predictions with the help of the method of regulating the items when the 
forecast of financial statement items is created taking into consideration the information about future management decisions. In this case, the previously described methods cannot be used because they will lead to the inadequate prediction. Strategic management decisions can radically alter the current balance structure; lead to a temporary decline in profitability, if there is a need for technical renovation, scientific research etc. This kind of prediction is used when the enterprise managers make essential, sometimes far from optimal in terms of finance, management decisions, which have a strategic nature and might be life-saving in the context of further competitive pressures.

The range of techniques for the preparation of projected financial statements stems from the needs of users of strategic financial information, the main ones of whom are the enterprise managers. The projected reports actually reflect the administration's idea of how the company will function in the future, taking into account possible changes in economic, social, political, legal, and competitive realities. For the analytics that are directly involved in the preparation of strategic financial information to support decision-making, an essential aspect of training is the possession of the basic tool for creating, processing, and analysing projected financial statements under uncertainty. The ability to prepare projected financial reports and to choose the optimal financial strategy for the future is a guarantee of avoidance of mistakes in business, the basis for management of financial and investment activity of the enterprise.

\section{Conclusions}

After the study, it is appropriate to conclude that metallurgy is a rather concentrated industry and, as a result, long-term trends in this area are rather predictable but it requires further refinements in terms of taking into account the uncertainty of the current state of the world economy. The dependence of the development of the metallurgical industry on the GDP indicator is established. The analysis showed that countries with high GDP have a well-developed metallurgy industry. One of the main problems of modern industry (including metallurgy) is the problem of corporate governance and how it responds to challenges of the environment, which is becoming less predictable for analysts. The main scientific and applied components of the advanced research methodology and its scientific concept are as follows:

It is proved on the basis of the development results of the method of determining the main characteristics of the implementation degree of the existing modern production enterprises' potential of the metallurgical industry of Ukraine, which, in the conditions of globalization, integration, and convergence processes of the world economy, arose the objective need and possibility of taking into account these strategic processes in the activities of domestic economic entities' objects, especially of ferrous metallurgy, which will promote not only increase of effective activity of separate industrial enterprises and growth of competitiveness of their products, but also in general, the intensification of the country's integration into the world economy.

The definition of the conceptual model of the influence of environmental determinants on the strategic changes of the ferrous metallurgy enterprises and the model of interaction between the enterprises of this sector and the corporation (holding) on the basis of the use of a methodical approach to the implementation of determinants of strategic management of metallurgy enterprises in the conditions of globalization, integration, and convergence, the introduction of which will contribute to sustainable growth of competitiveness, both for individual enterprises and for the economy as a whole.

\section{References:}

Besanko, D., Dranove, D., Shanley, M., \& Schaefer, S. (2009). Economics of strategy. John Wiley \& Sons.

Bouchaud, Jean-Philippe; Potters, Aguilar (1997). Missing Information and Asset Allocation.

Competitive Strategy: Techniques for Analyzing Industries and Competitors. - New York: The Free Press, 1980 (2nd ed. - New York: Free Press, 1998. - 397 p. - ISBN 978-0-684-84148-9);

Deming, W. E. (1982). Quality, productivity and competitive position. Cambridge, MA: Massachusetts Institute of Technology, Center for Advanced Engineering Study.

Goshel J. P., Noyria N. (1993). Horses for Courses: Organisation Forms for Multinational Corporations. Sloan Management Review, 23-25.

Grubel, Herbert? G.; Lloyd, Peter? J. (1975). Intra-industry trade: the theory and measurement of international trade in differentiated products. New York: Wiley. ISBN 0-470-33000-7.

Inkpen, A. C., Ramaswamy, K. (2006). Global strategy: creating and sustaining advantage across borders. N.Y.: Oxford University Press.

Levitt, T. (1983). The Globalization of Markets. Harvard Business Review, 61, 90-102.

Porter, M. E. (2008). The Five Competitive Forces That Shape Strategy, Harvard Business Review, January 2008, pp. 79-93.

Rowe, H., Mason, R. and Dickel, K. (1982). Strategic Management and Business Policy, a Methodological Approach, Reading, Massachusetts: Addison Wesley Publishing Co. Inc., 155 p.

The World Steel Association Official Website. Retrieved from: https://www.worldsteel.org/en/dam/jcr:3e275c736f11-4e7f-a5d8-23d9bc5c508f/Steel+Statistical+Yearbook+2017.pdf 